Final manuscript post-peer review, published in Science of The Total Environment 534, 122130.

\title{
Regime shifts, thresholds and multiple stable states in freshwater ecosystems; a critical appraisal of the evidence
}

Samantha J. Capon ${ }^{1 *}$, A. Jasmyn J. Lynch², Nick Bond ${ }^{3}$, Bruce C. Chessman², ${ }^{2,}$ Jenny

Davis $^{2}$, Nick Davison ${ }^{5}$, Max Finlayson ${ }^{5}$, Peter A. Gell ${ }^{6}$, David Hohnberg ${ }^{7}$, Chris Humphrey ${ }^{8}$

${ }^{9}$, Richard T. Kingsford ${ }^{4}$, Daryl Nielsen ${ }^{10}$, James R. Thomson ${ }^{2}$, Keith Ward ${ }^{11}$, and Ralph Mac Nally ${ }^{2}$

${ }^{1}$ Australian Rivers Institute, Griffith University, Nathan Queensland 4111, Australia

${ }^{2}$ Institute for Applied Ecology, University of Canberra, Bruce ACT 2601, Australia

${ }^{3}$ Victorian Department of Sustainability and Environment, Australia

${ }^{4}$ Centre for Ecosystem Science, UNSW Australia, NSW 2052, Australia

${ }^{5}$ Institute for Land, Water \& Society, Charles Sturt University, Albury, Australia

${ }^{6}$ Federation University Australia, Ballarat Vic 3353, Australia

${ }^{7}$ Murray Darling Basin Authority, Canberra ACT 2601, Australia

${ }^{8}$ Supervising Scientist Division, SEWPaC, Canberra ACT 2601, Australia (previous)

${ }^{9}$ Environmental Research Institute of the Supervising Scientist, Department of the

Environment, Darwin NT 0801, Australia (current)

${ }^{10}$ The Murray-Darling Freshwater Research Centre, CSIRO and Latrobe University, Wodonga, VIC, Australia

${ }^{11}$ Goulburn Broken Catchment Management Authority, Australia 
Corresponding author: $\quad$ Samantha J. Capon, Email: s.capon@griffith.edu.au, Phone: +61 (0) 402217899

Keywords: alternative stable states, catastrophic change, human pressures, phase shifts, change, sudden change, time series, thresholds

\section{Abstract}

The concepts of ecosystem regime shifts, thresholds and alternative or multiple stable states are used extensively in the ecological and environmental management literature. When applied to aquatic ecosystems, these terms are used inconsistently reflecting differing levels of supporting evidence among ecosystem types. Although many aquatic ecosystems around the world have become degraded, the magnitude and causes of changes, relative to the range of historical variability, are poorly known. A working group supported by the Australian Centre for Ecological Analysis and Synthesis (ACEAS) reviewed 135 papers on freshwater ecosystems to assess the evidence for pressure-induced non-linear changes in freshwater ecosystems; these papers used terms indicating sudden and non-linear change in their titles and key-words, and so was a positively biased sample. We scrutinized papers for study context and methods, ecosystem characteristics and focus, types of pressures and ecological responses considered, and the type of change reported (i.e. gradual, non-linear, hysteretic or irreversible change). There was little empirical evidence for regime shifts and changes between multiple or alternative stable states in these studies although some shifts between turbid phytoplankton-dominated states and clear-water, macrophyte-dominated states were reported in shallow lakes in temperate climates. We found limited understanding of the subtleties of the relevant theoretical concepts and encountered few mechanistic studies that investigated or identified cause-and-effect relationships between ecological responses and nominal pressures. Our results mirror those of reviews for estuarine, nearshore and marine aquatic ecosystems, demonstrating that although the concepts of regime shifts and alternative 
stable states have become prominent in the scientific and management literature, their empirical underpinning is weak outside of a specific environmental setting. The application of these concepts in future research and management applications should include evidence on the mechanistic links between pressures and consequent ecological change. Explicit consideration should also be given to whether observed temporal dynamics represent variation along a continuum rather than categorically different states.

\section{Highlights}

- Empirical evidence supporting regime shifts and multiple stable states in freshwater ecosystems was limited to studies of shallow temperate lakes that shift between macrophyte and phytoplankton dominance.

- Despite a diversification in the number and use of terms describing large, sudden ecological change (e.g. thresholds, regime shifts, alternative stable states), about $85 \%$ of publications assessed for freshwater ecosystems employing such terms lacked convincing supporting evidence or appropriate data.

- Few studies reported on parallel time series of ecosystem state and nominal pressures over sufficient periods to distinguish pressure-driven changes from natural variability. Reports of potential recovery of freshwater ecosystems were few; pressures were rarely alleviated so the 'stability' of alternative states could not be assessed.

- Inconsistent nomenclature and vague links with theory may lead to the inappropriate application of the concepts of regime shifts and multiple stable states in ecosystem management, particularly when changes are not stable, 
represent a continuum of change, or have not been assessed in the context of long-term historical variation. 


\section{Introduction}

Rapid and dramatic change in the structure and function of ecosystems due to human-induced pressures is of major concern to modern society, with high stakes associated with the impacts and management of such change. Of particular recent concern is the increasingly prevalent notion that dramatic ecological change can occur suddenly, and without warning, potentially causing stark or irreversible shifts in ecosystem state (Scheffer et al. 2001, Carpenter 2003, Mac Nally et al. 2014). Ecologists have conceptualized these ideas with terminology borrowed from engineering and other systems sciences so that non-linear ecological change is typically conceived as a shift in state from one relatively stable 'basin of attraction' or 'regime' to another, usually after an external trigger or disturbance tips the system over an unstable 'threshold'. Internal feedbacks are inferred to maintain ecosystems in particular states with varying degrees of 'resistance' (i.e. capacity to maintain a current state against a rising pressure) and 'resilience' (i.e. the capacity to recover once a pressure is relaxed) to disturbance (Harrison 1979). The potential for such 'ecological surprises' is often raised to support urgent management action to avoid 'tipping points' and consequent undesirable change (Scheffer \& Carpenter 2003, Lindenmayer et al. 2011). Conversely, terms such as regime shift are often invoked to argue that a system has already exceeded a critical ecological threshold and is residing either in an unstable phase or in an alternative, often novel, regime and therefore requires different management goals and tools (e.g. Walker et al. 2009). The regime-shift metaphor has profound implications for management choices and the development of appropriate aims, methods and interventions. It is vital that the evidence supporting this prominent conceptual framework be thoroughly and critically evaluated so that its relevance to particular ecosystems can be determined.

Ideas of ecological regime shifts, alternative or multiple stable states and thresholds are controversial (e.g. Peterson 1984, Groffman et al. 2006) and have recently come under 
increasing analytical scrutiny (e.g. Petraitis 2013, Mac Nally et al. 2014). Empirical evidence has been evaluated for a range of ecological systems, particularly marine environments and, most recently, in estuaries and nearshore ecosystems (Table 1). These assessments found few instances of regime shifts and multiple stable states, and generally concluded either that methodological approaches to the identification of multiple stable states were inadequate or that the concept was of little practical value (Bertness et al. 2002). The quest for valid evidence of regime shifts and multiple stable states appears to be hampered by three main impediments: (1) terminological proliferation and inconsistency; (2) inadequacy of the temporal and spatial resolution and scope of datasets for evaluating change in relation to the range of system variability; and (3) insufficient demonstration of mechanistic links between pressures and consequent ecological change (Peterson 1984, Mac Nally et al. 2014). Mac Nally et al. (2014) pointed out that the frequency of non-linear change relative to that of linear change has rarely been considered.

Freshwater ecosystems frequently are cited as exemplars of regime shifts and multiple stable states (Holling 1973; Carpenter et al. 2011), the classic case being a shift in shallow temperate lakes between clear-water, macrophyte-dominated states and turbid, phytoplankton-dominated states (Scheffer et al. 1993). However, we are unaware of any prior critical evaluation of the evidence for regime shifts and multiple stable states in freshwater ecosystems more generally. Understanding ecological change in freshwater ecosystems is especially important because they are among the world's most altered and damaged ecosystems yet have high socio-ecological interdependence and highly contested resource management and allocation (Vörösmarty et al. 2010; Capon et al. 2013). Freshwater ecosystems are likely to be extremely vulnerable to future changes in climate and other human pressures (Capon et al. 2013, Capon \& Bunn 2015). 
We examined the evidence for non-linear ecological change, including regime shifts, ecological thresholds, and multiple or alternative stable states, in freshwater ecosystems. We searched for published papers reporting abrupt ecological change and evaluated these with respect to their context, methods and results. Studies claiming to provide empirical evidence of ecological change were characterized according to the type of ecological change described and were assessed with criteria deemed relevant to establish convincing evidence of nonlinear change.

\section{Concepts and definitions}

A plethora of concepts and terms describe sudden, non-linear changes in ecosystems (Connell \& Sousa 1983, Lees et al. 2006, Mac Nally et al. 2014). For the most part, these concepts stem from equilibrial notions of ecosystem behaviour in which ecosystems are thought to persist in essentially stable states or gravitate towards other stable states in response to external forces (Connell \& Sousa 1983). Ecologists often use a ball-and-cup model to represent the potential for multiple ecosystem states to occur in the same place at different times, or at the same time in different places with otherwise identical environmental conditions (Holling et al. 1995). A central tenet of this theoretical structure is the existence of thresholds or tipping points between alternative states, at which ecosystems respond disproportionately (i.e. non-linearly) responses to incremental changes in pressure (Groffman et al. 2006).

Lees et al. (2006) identified four defining characteristics of regime-shift concepts as presented in the literature. First, they are sudden or abrupt. Second, they involve change in both physical and biological components. Third, they embody ecological change across multiple trophic levels. Fourth, they occur with high amplitude but low frequency; systems that vary with high frequency would be characterized as having high natural variability. For 
the sake of consistency, we use definitions provided by Mac Nally et al. (2014) to describe the key elements of this conceptual framework (Table 2). However, we retain the term 'regime shifts' to describe the process by which ecosystems change state irreversibly across thresholds or tipping points.

Regardless of the terminology used, multiple-stable-state theory invokes a fundamental distinction between gradual, monotonic ecological change in response to pressure and non-linear, discontinuous change in ecosystem response or state. In the latter case, several different types of non-linear change are possible (see concept figures of Gordon et al. 2008 and Mac Nally et al. 2014). First, non-linear change may involve a stepped change in an ecological variable with continuously applied pressure. Second, there may be a hysteretic relationship between the ecological response and the pressure whereby shifts in the ecosystem state occur at different threshold values depending on the direction of change. This is the model most commonly used to describe shifts between clear-water and turbid states in shallow lakes. A third potential type of non-linear change also involves hysteresis but is irreversible, even if pressures are removed or restoration actions are implemented.

\section{Demonstrating pressure-induced ecological change}

We do not consider the following studies to provide empirical evidence for pressure-induced change in ecosystem state (see Peterson’s criteria: Peterson 1984, Petraitis 2013): (1) theoretical or modelling studies; (2) field or ex situ small-scale or short-term experiments, especially those of shorter duration than the typical generation time of taxa within the target system; (3) space-for-time substitutions, which are commonly analysed but that do not provide site-specific sequences of ecosystem states and pressures; and (4) longer-term (100s to 1000 s of years) palaeoecological data series, given their different temporal context and often poor resolution of pressures, mechanisms and timescales of change. 
We advocate two requirements for convincing evidence of pressure-induced changes in an ecological response variable or ecosystem state. First, the time series of data for the response variable must be long enough to allow detection of a change point (Andersen et al. 2009) and to distinguish pressure-induced changes from 'normal' or historical variability (Nicholls 2011). Second, a corresponding time series is required for one or more putative anthropogenic (or natural) pressures to statistically relate to the change point (Thomson et al. 2010). If there is evidence that pressure has induced a change in ecosystem state, pressure release may be followed by a return of the response variable to its previous state, possibly after a lag if the system is hysteretic (Mac Nally et al. 2014). However, if the ecosystem state does not recover after pressure release, with or without restoration actions, there would be evidence for breaching of a tipping point and irreversible change occurring, which is important for ecosystem management. Establishing such irreversible change requires a pulsetype pressure trajectory to be demonstrated. Many analyses seek a single change point, but more generalized models allow for multiple shifts in the mean value, variance or rate of change of the response variable or ecosystem state and relate such shifts to temporal sequences of the pressure inducing them (Brock \& Carpenter 2006, Clements et al. 2010, Thomson et al. 2010).

\section{Methods}

We used the Thomson-ISI Web of Science database to identify papers reporting on non-linear change in freshwater ecosystems that were published before the $15^{\text {th }}$ of November 2012 . We searched paper titles using a combination of ecosystem type (i.e. 'river’, 'lake’, ‘stream', 'wetland', ‘freshwater', ‘estuar*', ‘swamp’, ‘floodplain', 'pond’ and 'marsh’) and change related search terms (i.e. 'threshold*', 'regime shift*', catastrophic, abrupt, alter* state, sudden) with '*' denoting a match-all wildcard. Other relevant papers known to us that were not returned by this search were added. We subsequently excluded papers that described 
changes in drivers or pressures only and those reporting solely on statistical methods for detecting ecological change. Literature reviews, theoretical papers and experimental studies that did not consider real-world data sets were also excluded, as were studies describing change on paleoecological timescales or short-term laboratory studies examining toxicological thresholds for freshwater biota. Papers that used terms such as regime shift without actually claiming to produce evidence of abrupt ecological change were eliminated from our analysis.

Shortlisted papers were then characterized with respect to their (1) spatial setting (location, climate zone, scale); (2) ecological focus (ecosystem type, taxa); (3) temporal context (time range, sampling frequency); (4) suite of pressures considered (major pressure type, temporal trajectory); and (5) research approach (field observations, experimental, space for time substitution). Instances of pressure-driven ecological change were categorized as potential cases of either gradual, non-linear, hysteretic or irreversible ecological change and the sufficiency of evidence for the non-gradual categories was assessed with respect to the criteria discussed above (Table 3).

\section{Results}

We initially found 135 papers from 1967 to 2011, mostly ( 85\%) published after 2000 (Supplementary material S1). Over half (53\%) concerned lake ecosystems while relatively few (c. 28\%) discussed lotic systems. 'Threshold' was the most common term used to describe abrupt ecological change (c. 31\% of papers) followed by 'regime shift' (23\% of papers) and 'alternative stable state' or a derivative (17\%). Earlier papers tended to use terms such as 'catastrophic', 'sudden' and 'abrupt' with 'regime shift' first appearing in the title of a 2001 paper (Scheffer et al. 2001). 
A shortlist of 50 papers (i.e. 37\%) comprised those that met our evaluative criteria (Table 3) and claimed to provide empirical evidence of stepped change or shifts in ecological regime or state (Table 4). Many of the excluded papers used terms such as regime shift without actually implying abrupt ecological change; most of these described high variance and relatively continuous parameter distributions.

Of the shortlisted papers, most related to North America or Europe (Supplementary material S2). Very few provided cases from Africa, Asia or South America, and none from Australasia. Correspondingly, most shortlisted papers concerned cases from temperate climates with few from tropical or arid regions (Supplementary material S3). The vast majority of cases (> 80\%) were from permanent freshwater systems with few semipermanent, or temporary, habitats discussed. Most cases (64\%) were from lentic ecosystems, especially shallow lakes, although there was a moderate number of studies on rivers and streams (Supplementary material S3). Macroinvertebrates, macrophytes and phytoplankton were the most commonly studied ecological response variables in the shortlisted cases (Supplementary material S4). Most papers (56\%) considered responses of only a single major taxon.

A range of anthropogenic and natural pressures was examined among the shortlisted papers (Supplementary material S5) although the majority (56\%) focused on ecological responses to a sole, major pressure type. Altered water quality, particularly nutrient addition, was the most common pressure investigated followed by hydrological and biological change. In most cases (68\%), the described pressures had press (i.e. suddenly increasing, then stable) or ramp (i.e. steadily increasing) trajectories that continued after initiation of the ecological change being described.

About half of the shortlisted papers focused on a single ecosystem (i.e. lake, stream or other wetland type) and a third of these measured ecological responses at only one or two 
sites. Many (63\%) of those studies that considered multiple ecosystems (or watersheds) were space-for-time substitutions examining ecological state at a single point in time across gradients of anthropogenic pressure, particularly levels of urbanisation. The 32 shortlisted papers presenting studies that were not space-for-time substitutions included seven experimental studies in which pressures were artificially manipulated (e.g. addition of nutrients or pressures). Most of these studies were conducted over short time periods relative to the processes being investigated (e.g. re-establishment of macrophytes; Supplementary material S6). The remaining instances that were not space-for-time substitutions presented field observations from specific studies, or longer-term monitoring programs, or a combination of both. The period of observation of these studies ranged from single surveys to over 100 years, although older observations tended to be anecdotal (Supplementary material S6).

Overall, 27 papers from the shortlist met Peterson’s (1984) criteria for demonstrating a pressure-induced ecological change, in that they were not space-for-time substitutions or short-term experimental studies, although two described natural seasonal, or supra-annual, variation (Table 4, Peterson 1984, Petraitis 2013). Nineteen (70\%) of these 27 papers claimed to provide evidence of pressure-driven non-linear, rather than gradual, changes in ecological response with 10 of these papers describing potential hysteresis, and two describing irreversible change (Table 4). Six of these 19 papers discussed alternative states in shallow lakes while another six concerned ecological responses to biological changes such as predator decline or addition, mostly in lakes. Instances of recovery from climatic events, including hydrological events, were reported in another five instances while the remainder concerned restoration trajectories. Only five of the 19 papers considered ecological responses to pulsed pressures with observations continuing beyond the release of the key pressure(s) being investigated. The remainder examined situations with press or ramp type pressures that were 
still occurring beyond the ecological state change being described. Feedback mechanisms, potentially maintaining the stability of ecological states, were explicitly considered in 11 of these papers.

\section{Evidence for pressure-induced non-linear ecological change}

We outline the few studies that provided some evidence for a non-linear change that could be attributed statistically to the effects of pressures. In many studies, the reported changes appeared to arise somewhat unexpectedly so there were few time sequences of ecosystem states (or component ecological responses) and even fewer time series for the associated pressures, a similar finding to that of Mac Nally et al. (2014) for estuarine studies. In such cases, attribution of cause generally was narrative (Bachmann et al., 1999). We found very few cases that provided even marginal support for pressure-induced alternative stable states. While different states seemed to occur, they often were unstable or transitory, or represented slow trajectories of change following pressure release, rather than demonstrating stasis being maintained by internal feedbacks.

Communities of benthic invertebrates in the upper Arkansas River in Colorado, USA appeared to respond to the release of a pressure, a clean-up of water quality, especially zinc removal (Clements et al. 2010). This study used a threshold-detection approach to determine the trajectory of benthic community change, but the study failed to link that change statistically to abundant water-quality information (Clements et al. 2010). Moreover, the study was conducted in the phase after pressure release and so the process of decline with increasing pressure was not documented.

There was also substantial evidence for stark changes in phytoplankton in the Bay of Quinte, north-eastern Lake Ontario, Canada (Nicholls et al. 2011). Reductions in phytoplankton biomass and changes in dominance by $\mathrm{N}$-fixing cyanobacteria were attributed 
to point-source reductions of phosphorus in 1978 and to the establishment of invasive dreissenid mussels in the mid-1990s. The analysis was extended to zooplankton, fish and benthic invertebrates, with largely similar interpretations (Nicholls 2011). While long-term (27 years) time series were available, the multivariate analytical approach together with correlated physical variables meant that it was not easy to attribute the cause of the observed changes.

Perhaps the most common form of alternative states discussed in the literature occurred in shallow lakes that switched between a clear-water, macrophyte-dominated state and a turbid, phytoplankton-dominated state (Scheffer et al. 1993). In many cases, these purported transitions occurred as nitrogen and phosphorus loads increased over time. Few studies demonstrated the maintenance of alternative stable state if nutrient loads were once again reduced, and thus failed to meet Peterson's criterion of demonstrating alternative stable states under similar environmental conditions. In other cases, the alternative states appeared to be relatively unstable. Examples of purported state changes (albeit lacking rigourous statistical tests) included a fish manipulation experiment in Lake Major, Hungary, in 1999_ 2000, whereby the lake was drained and much of the fish biomass was removed leading to a clear-water condition with high macrophyte cover by 2005-2006 (Tátrai et al. 2009). However, by 2007 the lake had once again become turbid, with increases in nitrogen, phosphorus and water temperature, and a recovery in fish abundances (Tátrai et al. 2009). Similar short-term responses to biomanipulation by the removal of bream (Abramis brama) and roach (Rutilus rutilus) with addition of pike (Esox lucius) were observed by Meijer and Hosper (2007). Last, shallow, naturally eutrophic lakes in the western Boreal Plain of Canada appeared to have a 'clear' state, dominated by submerged aquatic vegetation (SAV), and a turbid, algal-dominated state, but most of these lakes frequently alternated between states, usually in successive years (Bayley et al. 2007). Switches were related to total phosphorus 
and to cover of SAV, but harsh conditions 'reset' the biota in most winters so that the lakes did not achieve stable alternative states (Bayley et al. 2007).

\section{DISCUSSION}

Concepts of regime shifts, ecological thresholds and alternative stable states have gained much traction in the late $20^{\text {th }}$ and early $21^{\text {st }}$ centuries in research on and management of freshwater ecosystems (see Supplementary material S1). However, we found little evidence for pressure-induced, non-linear ecological change in contemporary freshwater ecosystems globally. Few studies in the literature presented data with a sufficient timespan and temporal resolution to adequately link anthropogenic pressures to observed ecological responses and to distinguish these from natural variability and even fewer met the relevant criteria for demonstrating regime shifts or multiple stable states (Table 3). These findings are consistent with reviews assembling and evaluating evidence for pressure-induced non-linear changes in other types of ecosystems (Table 1).

The most convincing evidence for pressure-induced non-linear ecological changes in freshwater ecosystems comes from shallow temperate lakes, in which shifts in ecosystem state between clear, macrophyte-dominated and turbid, phytoplankton-dominated states have frequently been observed (Scheffer et al. 1993, Scheffer 1998). Several cases (e.g. Blindow et al. 1993, Bachmann et al. 1999, Rip et al. 2006, Tátrai et al. 2009) demonstrated that such ecological changes are at least partly driven by changes in water chemistry or top-down biotic controls. While non-linear pressure-response relationships are apparent in a moderate number of these cases, evidence for multiple stable states or regime shifts in these systems is still scant because the different ecological states described typically occur under different environmental conditions (e.g. nutrient concentrations) and hence do not satisfy the criteria for demonstrating multiple stable states (Peterson 1984, Petraitis 2013). The stability of 
contrasting ecosystem states in shallow temperate lakes is rarely apparent in the instances described with forward and reverse shifts often occurring repeatedly or even seasonally (e.g. Bayley et al. 2007). Even in the few instance in which ecosystem state changes appear to have been triggered by, and persist beyond, pulse type pressures (e.g. hurricanes), other pressures (typically anthropogenic) are likely to have changed, preventing a return to the previous ecosystem state.

The establishment of macrophytes emerges as a critical process influencing the apparent hystereses in shallow temperate lakes, although few studies explicitly examined this process, instead recording changes in macrophyte cover or extent in relation to water quality or biological pressures. Environmental conditions necessary for the germination and regeneration of many macrophytes differ from those under which they can grow or spread vegetatively, often requiring drawdown of water levels (Cronk \& Fennesy 2001). Loss of macrophytes in lake systems may occur as a result of one pressure (e.g. reduced light levels due to increased turbidity), while their recovery may be limited by other pressures (e.g. the artificial maintenance of water levels). In such situations, apparent alternative stable states resulting from changes to water quality would not be truly hysteretic or irreversible in relation to the instigating pressure, instead reflecting the lack of a sufficient trigger or conditions for vegetation regeneration.

The influence of multiple pressures on freshwater ecosystems makes pressure-induced ecological change difficult to demonstrate from observational studies alone and reinforces a need for controlled experiments at the correct spatial and temporal scales to understand anthropogenic effects and to determine the appropriate management and restoration approaches (Scheffer \& Carpenter 2003, Petraitis \& Dudgeon 2004, Mac Nally et al. 2014). Apparent shifts in ecosystem state may occur commonly in some systems, such as temperate lakes, in the absence of major anthropogenic pressures (e.g. Bayley et al. 2007, Wang et al. 
2010). In highly modified landscapes (e.g. much of temperate Europe and North America), such naturally varying ecosystems are likely to be subjected to a wide range of anthropogenic pressures, the combined effects of which could prevent or slow down natural cycles of climatically or hydrologically driven variability.

Our assessment highlighted several practical obstacles to empirically demonstrating pressure-induced, non-linear change. In particular, the data collection requirements are substantial; datasets need to have sufficient duration, extent and spatial and temporal resolution to adequately link pressures and ecological responses. Given the complex interaction of multiple pressures in freshwater ecosystems (Ormerod et al. 2010), obtaining data for a satisfactory range of potentially important pressures can also be difficult. Even with sufficiently detailed datasets, statistically demonstrating pressure-induced non-linear ecological change can be impeded by high natural variability of responses and pressures (Thomson et al. 2010, Nicholls 2011). Stark ecological changes are usually unexpected and so data are seldom available for ecological responses and pressures prior to observed changes (Mac Nally et al. 2014).

How long do field-based studies need to be run to provide evidence of non-linear change? The minimum duration of a study depends on the ecological response being considered. If the response is the population dynamics of a focal organism, then one could not expect to make an assessment without having followed the process for at least one generation. Even this duration is likely to be insufficient because extinction debt may mask the loss of long-term viability. In such cases population viability models provide one approach of extrapolating data on reproduction and survival collected over shorter timescales. Other phenomena such as the loss of long-lived macrophyte seed banks or crustacean egg banks may involve periods far in excess of the organism's active life-span or generation length. Thus, the selection of environmental and ecological-response variables and the 
duration and temporal resolution of observations must relate to the longevity and life-history of the organism, the probable mechanisms of change (e.g. aquatic vegetation regeneration), and account for seasonal and other natural cycles of variation that may be relevant (e.g. El Niño Southern Oscillation, Pacific Decadal Oscillation).

The theory of regime shifts, ecological thresholds and alternative stable states has struck a chord with the management (and managers) of freshwater ecosystems (e.g. Clements et al. 2010, Carpenter et al. 2011). A degree of ecological inertia and resilience to human pressures are implicit in these concepts, fostering the comforting notion that ecosystems can tolerate or absorb a certain amount of pressure without suffering adverse changes. In situations where detrimental ecological changes have already occurred, this theory implies that great improvements in ecological conditions might be achieved with relatively small reductions in anthropogenic pressures (Mac Nally et al. 2014). However, if gradual, monotonic changes are the norm, then ecological objectives may only be achieved only with reductions in human pressures commensurate to the degree of change desired.

Our finding of scant evidence for pressure-induced non-linear changes in freshwater ecosystems implies that such changes are much rarer than gradual, monotonic changes and high temporal variability. This conclusion differs from the expectation one might draw from the frequency with which terms such as 'alternative stable states' and 'regime shifts' appear in the title and keywords of published papers. While it can be difficult to test for positive biases in the literature (i.e. the tendency to publish only studies that conform to or support a particular hypothesis), our analysis revealed a different problem of falsely associating theoretical constructs with results that do not credibly support them. While these issues have been widely discussed in the broad ecological literature (e.g. see Petraitis 2013), this problem seems increasingly prevalent for freshwater systems, where these concepts have an especially high profile (e.g. Scheffer et al., 1993). 
The inconsistent and often vague use of terms that we have reviewed does not completely undermine the evidence base for large-scale or rapid ecological change due to natural or anthropogenic processes; we do not dispute that these occur and are responsible for widespread loss of biodiversity and degradation of ecosystems (Millennium Ecosystem Assessment 2005). Similarly, the capacity of freshwater ecosystems to recover from non-human disturbances (e.g. climatic or hydrological anomalies) may be greatly reduced with increasing anthropogenic pressures (Capon et al. 2013). However, there is a clear need for much greater refinement and more consistent use of nomenclature relating to pressure-induced ecological change in ecosystems to distinguish among gradual, nonlinear, hysteretic and potentially irreversible change (sensu Gordon et al. 2008), and to separate such directed change from stationary but highly variable systems. As the need to document, understand and manage ecological changes grows, so does the requirement for greater rigour in data collection and reporting, especially with respect to its temporal range and resolution and analysis. Analytical methods need to routinely propagate uncertainties in measurements of both response and pressure variables because apparently sharp changes may diminish once uncertainties are accounted for (Mac Nally et al. 2014).

More attention must be paid to the use and potential misuse of ecological theory in trying to predict future ecosystems trajectories. Such issues strengthen the need for long-term ecological monitoring of freshwater systems with data collection protocols firmly grounded in conceptual models. An emphasis is needed on processes and mechanisms of potential change and the measurable quantities that capture relationships between the trajectories of responses and pressures (Mac Nally et al. 2014). 


\section{Acknowledgments}

We are most grateful to the Australian Centre for Ecological Analysis and Synthesis for supporting the working group: A cup half-full? Thresholds and regime shifts in Australian freshwater systems. We thank Alison Specht for her encouragement and unquenchable enthusiasm. S.C. was supported by a Griffith University Research Fellowship. R.M. and J.R.T were supported by Australian Research Council Grant DP120100797.

\section{Supporting information}

Appendix 1. A list of the 135 papers that we identified in a search of the Thomson-ISI Web of Science. 


\section{References}

Bachmann, R. W., Hoyer, M. V. and Canfield Jr, D. E. (1999) The restoration of Lake Apopka in relation to alternative stable states. Hydrobiologia 394: 219-232.

Bayley, S. E., Creed, I. F., Sass, G. Z. and Wong, A. S. (2007) Frequent regime shifts in trophic states in shallow lakes on the Boreal Plain: Alternative" unstable" states? Limnology and Oceanography 52: 2002-2012.

Bertness, M. D., Trussell, G. C., Ewanchuk, P. J. and Silliman, B. R. (2002) Do alternate stable community states exist in the Gulf of Maine rocky intertidal zone? Ecology 83: 3434-3448.

Blindw, I., Andersson, G., Hargeby, A., Johansson, S. (1993) Long-term pattern of alternative stable states in two shallow eutrophic lakes. Freshwater Biology 30: 159167.

Brock, W. A., \& Carpenter, S. R. (2006) Variance as a leading indicator of regime shift in ecosystem services. Ecology and Society 11: 9.

Capon, S. J., Chambers, L. E., Mac Nally, R., Naiman, R. J., Davies, P., Marshall, N., Pittock, J.,Reid, M., Capon, T., Douglas, M., Catford, J., Baldwin, D.S., Stewardson, M., Roberts, J., Parsons, M. and Williams, S.E. (2013) Riparian Ecosystems in the 21st Century: Hotspots for Climate Change Adaptation? Ecosystems (16): 359-381.

Capon, S. J. and Bunn, S. E. (2015). Chapter 3. Assessing climate change risks and prioritising adaptation options using a water ecosystem services approach. In Water Ecosystem Services, Cambridge University Press, Cambridge.

Carpenter, S. R. (2003) Regime shifts in lake ecosystems: pattern and variation. International Ecology Institute, Oldendorf/Luhe. 
Carpenter, S. R., Cole, J. J., Pace, M. L., Batt, R., Brock, W. A., Cline, T., Coloso, J., Hodgson, J. R., Kitchell, J. F., Seekell, D. A. and Weidel, B. (2011). Early warnings of regime shifts: a whole-ecosystem experiment. Science 332: 1079-1082.

Clements, W. H., Vieira, N. K. M. and Sonderegger, D. L. (2010) Use of ecological thresholds to assess recovery in lotic ecosystems. Journal of the North American Benthological Society 29: 1017-1023.

Connell, J. H. and Sousa, W. P. (1983) On the evidence needed to judge ecological stability or persistence. The American Naturalist 121: 789-824.

Cronk, J.K. and Fennessy, M. S. (2001) Wetland Plants: Biology and Ecology. CRC Press/Lewis Publishers. Boca Raton, FL. 440 pages.

Gordon, L. J., Peterson, G. D. and Bennett, E. M. (2008) Agricultural modifications of hydrological flows create ecological surprises. Trends in Ecology and Evolution 23: 211-219.

Groffman, P. M., Baron, J. S., Blett, T., Gold, A. J., Goodman, I., Gunderson, L. H., Levinson, B. N., Palmer, M. A., Paerl, H. W., Peterson, G. D., Poff, N. L., Rejeski, D. W., Reynolds, J. F., Turner, M. G., Weathers, K. C. and Wiens, J. (2006) Ecological thresholds: the key to successful environmental management or an important concept with no practical application? Ecosystems 9:1-13.

Harrison, G.W. (1979) Stability under environmental stress: resistance, resilience, persistence, and variability. The American Naturalist 113: 659-669.

Holling, C. S., Schindler, D. W., Walker, B. W. and Roughgarden, J. (1995) Biodiversity in the functioning of ecosystems: an ecological synthesis. In Biodiversity Loss: 
Economic and ecological Issues. (Ed. C. Perrigs and K. Maler) Cambridge University Press, Cambridge. Pp. 44-83.

Holling, C. S. (1973). Resilience and stability of ecological systems. Annual Review of Ecology and Systematics, 1-23.

Lees, K., Pitois, S., Scott, C., Frid, C. and Mackinson, S. (2006). Characterizing regime shifts in the marine environment. Fish and Fisheries 7: 104-127.

Lindenmayer, D. B., Hobbs, R. J., Likens, G. E., Krebs, C. J. and Banks, S. C. (2011). Newly discovered landscape traps produce regime shifts in wet forests. PNAS 108: 1588715891.

Mac Nally, R., Albano, C. and Fleishman, E. (2014) A scrutiny of the evidence for pressureinduced state shifts in estuarine and nearshore ecosystems. Austral Ecology 39: 898906.

Millennium Ecosystem Assessment (2005) Millennium Ecosystem Assessment Findings. Millennium Ecosystem Assessment.

Nicholls, K. H. (2011) Detection of regime shifts in multi-species communities: the Bay of Quinte phytoplankton example. Methods in Ecology and Evolution 2: 416-426.

Nicholls, K. H., Hoyle, J. A., Johannsson, O. E. and Dermott, R. (2011) A biological regime shift in the Bay of Quinte ecosystem (Lake Ontario) associated with the establishment of invasive dreissenid mussels. Journal of Great Lakes Research 37: 310-317.

Ormerod S. J., Dobson M., Hildrew, A. G. and Townsend, C. R. (2010) Multiple stressors in freshwater ecosystems. Freshwater Biology 55: 1-4. 
Peterson, C. H. (1984) Does a rigorous criterion for environmental identity preclude the existence of multiple stable points? The American Naturalist 124: 127-133.

Petraitis, P. (2013) Multiple Stable States in Natural Ecosystems. Oxford University Press, Oxford.

Petraitis, P. S. and Dudgeon, S. R. (2004) Detection of alternative stable states in marine communities. Journal of Experimental Marine Biology and Ecology 300: 343- 371.

Rip, W. J., Rawee, N., de Jong, A. (2006) Alternation between clear, high-vegetation and turbid, low-vegetation states in a shallow lake: the role of birds. Aquatic Botany 85: 184-190.

Scheffer, M., Hosper, S. H., Meijer, M. L., Moss, B., \& Jeppesen, E. (1993) Alternative equilibria in shallow lakes. Trends in Ecology \& Evolution 8: 275-279.

Scheffer, M. (1998) Ecology of Shallow Lakes. Chapman and Hall, London.

Scheffer, M., Carpenter, S., Foley, J. A., Folke, C. and Walker, B. (2001) Catastrophic shifts in ecosystems. Nature 413: 591-596.

Scheffer, M., Straile, D., van Nes, E. H., and Hosper, H. (2001) Climatic warming causes regime shifts in lake food webs. Limnology and Oceanography 46: 1780-1783.

Scheffer, M. and Carpenter, S. R. (2003) Catastrophic regime shifts in ecosystems: linking theory to observation. Trends in Ecology and Evolution 18: 648-656.

Scheffer, M., Hosper, S. H., Meijera, M. L., Moss, B. and Jeppesen, E. (1993) Alternative equilibria in shallow lakes. Trends in Ecology and Evolution 8: 275-279.

Spencer, M., Birchenough, S. N. R., Mieszkowska, N., Robinson, L. A., Simpson, S. D., Burrows, M. T., Capasso, E., Cleall-Harding, P., Crummy, J., Duck, C., Eloire, D., 
Frost, M., Hall, A.J., Hawkins, S. J., Johns, D. G., Sims, D. W., Smyth, T. J. and Frid, C. L. J. (2011) Temporal change in UK marine communities: trends or regime shifts? Marine Ecology 32(s1): 10-24.

Tátrai, I., Boros, G., György, Á. I., Mátyás, K., Korponai, J., Pomogyi, P., Havasi, M. and Kucserka, T. (2009) Abrupt shift from clear to turbid state in a shallow eutrophic, biomanipulated lake. Hydrobiologia 620: 149-161.

Thomson J. R., Kimmerer W., Brown L., R., Newman, K. B., Mac Nally, R. M., Bennett, W. A., Feyrer, F and Fleishman, E. (2010) Bayesian change-point analysis of temporal patterns in fish abundances in the upper San Francisco estuary. Ecological Applications 20: 1431-48.

Vörösmarty, C. J., McIntyre, P. B., Gessner, M. O., Dudgeon, D., Prusevich, A., Green, P., Glidden, S., Bunn, S. E., Sullivan, C. A., Reidy Liermann, C. and Davies, P. M. (2010) Global threats to human water security and river biodiversity. Nature 467: $555-561$.

Walker, B., Abel, N. , Anderies, J. M. and Ryan, P. (2009) Resilience, adaptability and transformability in the Goulburn-Broken Catchment, Australia. Ecology and Society 14: 12 .

Wan, Y. C., Wang, Z. C., Wu, W. J., Hu, M. M., Wang, Z., Xu, A. H., Li, G. B., Liu, Y. D. (2010) Seasonal regime shift of an alternative-state Lake Xingyun, China. Fresenius Environmental Bulletin 19: 1474-1485. 
Table 1. Summary of papers examining evidence for ecological regime shifts

\begin{tabular}{|c|c|c|c|}
\hline Citation & Description & Ecological system(s) & Findings \\
\hline $\begin{array}{l}\text { Connell \& } \\
\text { Sousa (1983) }\end{array}$ & $\begin{array}{l}\text { Review of instances } \\
\text { cited by theoretical } \\
\text { papers }\end{array}$ & Range & $\begin{array}{l}\text { Instances reviewed all found to have at least one of following } \\
\text { shortcomings: 1.) physical environment differs between alternative } \\
\text { states, 2.) alternative states persist only when artificial controls } \\
\text { (pressures) maintained, 3.) evidence simply inadequate }\end{array}$ \\
\hline \multirow[t]{2}{*}{$\begin{array}{l}\text { Petraitis \& } \\
\text { Dudgeon } \\
(2004)\end{array}$} & \multirow{2}{*}{$\begin{array}{l}\text { Assessment of } \\
\text { published experiments } \\
\text { against Peterson’s } \\
\text { (1984) criteria }\end{array}$} & \multirow[t]{2}{*}{ Marine } & $\begin{array}{l}\text { Limited evidence found for alternative stable states due to lack of } \\
\text { experimental studies in coral reefs, rocky intertidal shores and soft } \\
\text { sediment habitats }\end{array}$ \\
\hline & & & $\begin{array}{l}\text { Kelp forests and coralline barrens meet criteria for alternative } \\
\text { stable states }\end{array}$ \\
\hline $\begin{array}{l}\text { Lees et al. } \\
(2006)\end{array}$ & $\begin{array}{l}\text { Assessment of case } \\
\text { studies against defining } \\
\text { criteria (N.B. lacking } \\
\text { criteria for stability or } \\
\text { self-maintenance) }\end{array}$ & Marine & $\begin{array}{l}\text { Regime shifts identified but not demonstrated to be pressure- } \\
\text { induced or stable }\end{array}$ \\
\hline $\begin{array}{l}\text { Spencer et al. } \\
(2011)\end{array}$ & $\begin{array}{l}\text { Regime shift detection } \\
\text { analysis of over } 300 \\
\text { biological time series }\end{array}$ & Marine & $\begin{array}{l}\text { Apparent regime shifts determined to be artefacts of temporal } \\
\text { trends rather than true regime shifts }\end{array}$ \\
\hline $\begin{array}{l}\text { Mac Nally et } \\
\text { al. (2014) }\end{array}$ & Literature review & $\begin{array}{l}\text { Estuarine and near- } \\
\text { shore }\end{array}$ & $\begin{array}{l}\text { Most instances reviewed lacked evidence of 'stark' ecological } \\
\text { changes with most drawing on space for time substitutions rather } \\
\text { than time-series data. Eight instances identified with compelling } \\
\text { evidence of stark changes. }\end{array}$ \\
\hline
\end{tabular}


Table 2. Definitions of terms in our analysis of change in ecosystem states (adapted from Mac Nally et al. 2014).

\begin{tabular}{|c|c|}
\hline Term & Definition \\
\hline Ecological response & $\begin{array}{l}\text { A time series of values of an individual component of } \\
\text { ecosystem state, such as the abundance of a taxon or a rate } \\
\text { of an ecological process (e.g., primary production). }\end{array}$ \\
\hline Ecosystem state & $\begin{array}{l}\text { A numerical description of an ecosystem that includes one or } \\
\text { more ecological responses, such as relative abundances of } \\
\text { plankton species or primary productivity. This definition } \\
\text { does not imply that the ecosystem state is equilibrial or } \\
\text { stationary; rather, ecosystem state is a time-varying vector } \\
\text { of ecological responses. }\end{array}$ \\
\hline Pressure & $\begin{array}{l}\text { A perturbation, typically human-induced, that affects an } \\
\text { ecosystem state or ecological response and that may be } \\
\text { transient (a pulse), persistent (a press), or monotonically } \\
\text { changing in magnitude (ramping) over time. }\end{array}$ \\
\hline Driver & $\begin{array}{l}\text { A spatially and temporally extensive source of change, } \\
\text { typically anthropogenic, that may induce multiple } \\
\text { pressures. For example, anthropogenic climate change } \\
\text { produces multiple pressures such as increases in } \\
\text { temperature or frequencies of storm events and } \\
\text { exacerbation of droughts. }\end{array}$ \\
\hline Ecological threshold & $\begin{array}{l}\text { The value of a pressure at which small pressure changes } \\
\text { induce a disproportionate change in an ecological response } \\
\text { or ecosystem state. }\end{array}$ \\
\hline Tipping point & $\begin{array}{l}\text { An ecological threshold beyond which a former ecosystem } \\
\text { state cannot be regained even when the pressure is } \\
\text { released and restoration actions (e.g., provision of } \\
\text { propagules) are undertaken. Synonymous with irreversible } \\
\text { change. }\end{array}$ \\
\hline $\begin{array}{l}\text { Multiple or alternative stable } \\
\text { states }\end{array}$ & $\begin{array}{l}\text { Ecosystem states before and after a tipping point, often held } \\
\text { to be maintained by feedback mechanisms (Scheffer et al., } \\
\text { 1993; Gordon et al., 2008). }\end{array}$ \\
\hline Regime shift & $\begin{array}{l}\text { The process whereby an ecosystem changes from one } \\
\text { alternative stable state to another. }\end{array}$ \\
\hline
\end{tabular}

Table 3. Criteria used to assess studies for evidence of regime shifts or multiple stable states. 


\begin{tabular}{|c|c|c|}
\hline Criterion & Rationale & Reference(s) \\
\hline $\begin{array}{l}\text { 1. Is not a purely theoretical or } \\
\text { modelling study (Peterson's } \\
\text { criteria) }\end{array}$ & $\begin{array}{l}\text { Does not provide } \\
\text { empirical evidence }\end{array}$ & $\begin{array}{l}\text { Peterson (1984), } \\
\text { Petraitis (2013), } \\
\text { Mac Nally et al. } \\
\text { (2014) }\end{array}$ \\
\hline $\begin{array}{l}\text { 2. Is not a field or ex situ } \\
\text { small-scale or short-term } \\
\text { experiment (Peterson's } \\
\text { criteria) }\end{array}$ & $\begin{array}{l}\text { Cannot account for natural } \\
\text { variability }\end{array}$ & $\begin{array}{l}\text { Peterson (1984), } \\
\text { Anderson et al. } \\
\text { (2009), Petraitis } \\
\text { (2013) }\end{array}$ \\
\hline $\begin{array}{l}\text { 3. Is not a space-for-time } \\
\text { substitution (Peterson's } \\
\text { criteria) }\end{array}$ & $\begin{array}{l}\text { Cannot account for spatial } \\
\text { differences in } \\
\text { environmental } \\
\text { conditions }\end{array}$ & $\begin{array}{l}\text { Peterson (1984), } \\
\text { Petraitis (2013) }\end{array}$ \\
\hline $\begin{array}{l}\text { 4. Is not based on a paleo- } \\
\text { ecological time series } \\
\text { (Peterson's criteria) }\end{array}$ & $\begin{array}{l}\text { Different temporal } \\
\text { context, poor resolution } \\
\text { of drivers, mechanisms } \\
\text { and timescales of } \\
\text { change }\end{array}$ & Petraitis (2013) \\
\hline $\begin{array}{l}\text { 5. Time series sufficiently long } \\
\text { to detect change points and } \\
\text { distinguish natural variability }\end{array}$ & $\begin{array}{l}\text { Needs to be longer than } \\
\text { generation time of } \\
\text { target taxa }\end{array}$ & $\begin{array}{l}\text { Peterson (1984), } \\
\text { Anderson et al. } \\
\text { (2009), Nicholls } \\
\text { (2011), Petraitis } \\
\text { (2013) }\end{array}$ \\
\hline $\begin{array}{l}\text { 6. Presents corresponding time } \\
\text { series for pressures and } \\
\text { ecological responses }\end{array}$ & $\begin{array}{l}\text { Pressure-induced change } \\
\text { cannot otherwise be } \\
\text { demonstrated nor } \\
\text { potential mechanisms } \\
\text { posited }\end{array}$ & $\begin{array}{l}\text { Thomson et al. (2010), } \\
\text { Mac Nally et al. } \\
\text { (2014) }\end{array}$ \\
\hline $\begin{array}{l}\text { 7. Implicated pressure follows } \\
\text { a pulse trajectory }\end{array}$ & $\begin{array}{l}\text { Hysteretic or non-linear } \\
\text { change in ecological } \\
\text { response or ecosystem } \\
\text { state cannot be } \\
\text { demonstrated if press } \\
\text { or ramp type pressures } \\
\text { still persist }\end{array}$ & Petraitis (2013) \\
\hline
\end{tabular}


Table 4. Shortlisted papers potentially presenting evidence of non-linear, pressure-induced ecological change in freshwater ecosystems. Key to columns: Data type: o = observed, e = experimental; Satisfies Peterson's criteria?: Numbers in brackets indicate main reasons for assessment: (1) space-for-time substitution study, (2) short-term experimental study and (3) insufficient presentation of data (Peterson 1984); Pressure trajectory: $p r=p r e s s, ~ p u=p u l s e, ~ r=~ r a m p ~(N . B$. not applicable for space-for-time substitution studies); Ecological change type described: $\mathrm{NV}=$ natural variability, $\mathrm{G}=$ gradual, $\mathrm{N}=$ non-linear, $\mathrm{H}=$ hysteresis, I = irreversible.

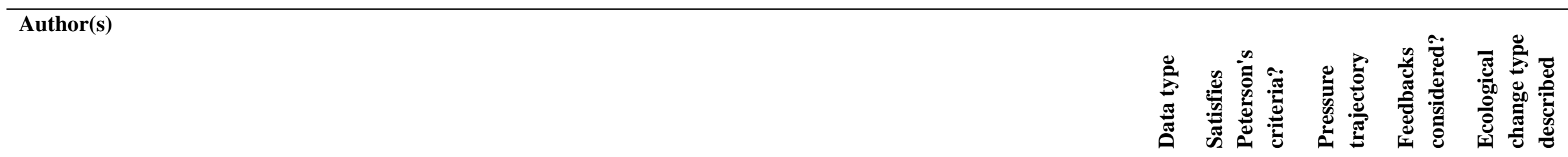

Bachmann, RW, Hoyer, MV, Canfield, DE (1999) The restoration of Lake Apopka in relation to alternative stable states. Hydrobiologia 394: 219-232.

Baker, ME, King RS (2010) A new method for detecting and interpreting biodiversity and ecological community thresholds. Methods in Ecology \& Evolution 1: 25-37.

Bayley, SE, Creed, IF, Sass, GZ, Wong, AS (2007) Frequent regime shifts in trophic states in shallow lakes on the Boreal Plain: Alternative "unstable" states? Limnology \& Oceanography 52: 2002-2012.

Bayley, SE, Prather, CM (2003) Do wetland lakes exhibit alternative stable states? Submersed aquatic vegetation and chlorophyll in western boreal shallow lakes. Limnology \& Oceanography 48: 2335-2345

Black RW, Moran PW, Frankforter JD (2011) Response of algal metrics to nutrients and physical factors and identification of nutrient thresholds in agricultural streams. Environmental Monitoring \& Assessment 175: 397-417

Blindow, I, Andersson, G, Hargeby, A, Johansson, S. (1993) Long-term pattern of alternative stable states in two shallow eutrophic lakes. Freshwater Biology 30: 159-167

Brenden TO, Wang L, Su Z (2008) Quantitative identification of disturbance thresholds in support of aquatic resource management. Environmental Management 42: 821-832.
0

o

no $(1)$

$\mathrm{pr}$

yes

N, H

0

pu

no

0

no (1) N/A no

$\mathrm{N}$

o

no (1) N/A N/A

o

r yes

N, H 
Carpenter, SR, Cole, JJ, Pace, ML, Batt, R, Brock, WA, Cline, T, Coloso, J, Hodgson, JR, Kitchell, JF, Seekell, DA,

Smith, L, Weidel, B (2011) Early warnings of regime shifts: a whole-ecosystem experiment. Science 332: 1079-1082

Clements WH, Vieira NKM, Sonderegger DL (2010) Use of ecological thresholds to assess recovery in lotic ecosystems. Journal of the North American Benthological Society 29: 1017-1023.

Connelly, S, Pringle, CM, Bixby, RJ, Brenes, R, Whiles, MR, Lips, KR, Kilham, S, Huryn, AD (2008) Changes in stream primary producer communities resulting from large-scale catastrophic amphibian declines: can small-scale experiments predict effects of tadpole loss?. Ecosystems 11: 1262-1276.

Cuffney TF, Qian SS, Brightbill RA, May JT, Waite IR (2010) Responses of benthic macroinvertebrates to environmental changes associated with urbanization in nine metropolitan areas. Ecological Applications 20: 1384-1401

Dermott, R (2001) Sudden disappearance of the amphipod Diporeia from Eastern Lake Ontario, 1993-1995. Journal of Great Lakes Research 27: 423-433.

Dokulil, MT, Donabaum, K, Teubner, K (2007) Modifications in phytoplankton size structure by environmental constraints induced by regime shifts in an urban lake. Hydrobiologia 578: 59-63

Elmer, WH, Robertson, CL, Useman, S, Schneider, RL, O'Donnell, K, O'Donnell, K (2007) Fusarium species associated with declining Spartina spp. in areas affected by sudden wetland dieback. Phytopathology 97: S178

Grenier M, Lavoie I, Rousseau AN, Campeau S (2010) Defining ecological thresholds to determine class boundaries in a bioassessment tool: The case of the Eastern Canadian Diatom Index (IDEC). Ecological Indicators 10: 980-989.

Hart, RC (2001) Two calanoids, two lakes, and a decade or two. An updated record and evaluation of occurrence and periodicity of Tropodiaptomus spectabilis and Metadiaptomus meridianus (Copepoda : Calanoida), and alternative stable states in two cascading impoundments. Hydrobiologia 453: 269-283.

Heffernan, JB (2008) Wetlands as an alternative stable state in desert streams. Ecology 89: 1261-1271.

Heffernan, JB, Sponseller, RA, Fisher, SG (2008) Consequences of a biogeomorphic regime shift for the hyporheic zone of a Sonoran Desert stream. Journal of the North American Benthological Society 53: 1954-1968.

King RS, Baker ME (2010) Considerations for analyzing ecological community thresholds in response to anthropogenic environmental gradients. Journal of the North American Benthological Society 29: 998-1008. 
King RS, Baker ME, Kazyak PF, Weller DE (2011) How novel is too novel? Stream community thresholds at exceptionally low levels of catchment urbanization. Ecological Applications 21, 1659-1678.

Lindig-Cisneros, R, Desmond, J, Boyer, KE, Zedler, JB (2003) Wetland restoration thresholds: Can a degradation transition be reversed with increased effort? Ecological Applications 13: 193-205

Loverde-Oliveira, SM, Huszar, VLM, Mazzeo, N, Scheffer, M (2009) Hydrology-Driven Regime Shifts in a Shallow Tropical Lake. Ecosystems 12: 807-819

Lowe, EF, Battoe, LE, Coveney, MF, Schelske, CL, Havens, KE, Marzolf, ER, Reddy, KR (2001) The restoration of Lake Apopka in relation to alternative stable states: an alternative view to that of Bachmann et al. (1999) Hydrobiologia 448: 11-18.

Marin, VH, Tironi, A, Delgado, LE, Contreras, M, Novoa, F, Torres-Gomez, M, Garreaud, R, Vila, I, Serey, I (2009) On the sudden disappearance of Egeria densa from a Ramsar wetland site of Southern Chile: A climatic event trigger model. Ecological Modelling 220: 1752-1763.

Nicholls KH (2011) Detection of regime shifts in multi-species communities: the Bay of Quinte phytoplankton example. Methods in Ecology \& Evolution 2: 417-426

Nicholls, KH, Hoyle, JA, Johannsson, OE, Dermott, R (2011) A biological regime shift in the Bay of Quinte ecosystem (Lake Ontario) associated with the establishment of invasive dreissenid mussels. Journal of Great Lakes Research 37 : 310-317

O'Farrell, I, Izaguirre, I, Chaparro, G, Unrein, F, Sinistro, R, Pizarro, H, Rodriguez, P, Pinto, PD, Lombardo, R, Tell, G (2011) Water level as the main driver of the alternation between a free-floating plant and a phytoplankton dominated state: a long-term study in a floodplain lake. Aquatic Science 73: 275-287

Padisak, J (1998) Sudden and gradual responses of phytoplankton to global climate change: Case studies from two large, shallow lakes (Balaton, Hungary, and the Neusiedlersee, Austria/Hungary). Management of Lakes and Reservoirs during Global Climate Change 42: 111-125

Peckham, SD, Chipman, JW, Lillesand, TM, Dodson, SI (2006) Alternate stable states and the shape of the lake trophic distribution. Hydrobiologia 571: 401-407 no (1) N/A 
Persson, L, Amundsen, PA, De Roos, AM, Klemetsen, A, Knudsen, R, Primicerio, R (2007) Culling prey promotes predator recovery - Alternative states in a whole-lake experiment. Science 316: 1743-1746

Petty, JT, Fulton, JB, Strager, MP, Merovich, GT, Stiles, JM, Ziemkiewicz, PF (2010) Landscape indicators and thresholds of stream ecological impairment in an intensively mined Appalachian watershed. Journal of the North American

Pillay, D, Branch, GM, Forbes, AT (2008) Habitat change in an estuarine embayment: anthropogenic influences and a regime shift in biotic interactions. Marine Ecology Progress Series 370: 19-31.

Rip, WJ, Rawee, N, de Jong, A (2006) Alternation between clear, high-vegetation and turbid, low-vegetation states in a shallow lake: the role of birds. Aquatic Botany 85: 184-190

Robinson, CT, Uehlinger, U(2008) E floods cause ecosystem regime shift in a regulated river. Ecological Applications 18 511-526

Roelke, DL, Zohary, T, Hambright, KD, Montoya, JV (2007) Alternative states in the phytoplankton of Lake Kinneret, Israel (Sea of Galilee). Freshwater Biology 52: 399-411.

Scheffer, M, Straile, D, van Nes, EH, Hosper, H (2001) Climatic warming causes regime shifts in lake food webs. Limnology \& Oceanography 46: 1780-1783

Tatrai, I, Boros, G, Gyorgy, A, Matyas, K, Korponai, J, Pomogyi, P, Havasi, M, Kucserka, T (2009) Abrupt shift from clear to turbid state in a shallow eutrophic, biomanipulated lake. Hydrobiologia 602: 149-161

Utz RM, Hildebrand RH \& Boward DM (2009) Identifying regional differences in threshold responses of aquatic invertebrates to land cover gradients. Ecological Indicators 9: 556-567. 
Waters, MN, Piehler, MF, Smoak, JM, Martens, CS (2010) The development and persistence of alternative ecosystem states in a large, shallow lake. Freshwater Biology 55: 1249-1261

Welsh, HH, Hodgson, GR (2008) Amphibians as metrics of critical biological thresholds in forested headwater streams of the Pacific Northwest, USA. Freshwater Biology 53: 1470-1488

Zambrano, L, Hinojosa, D (1999) Direct and indirect effects of carp (Cyprinus carpio) on macrophytes and benthic communities in shallow ponds in central Mexico. Hydrobiologia 408/409: 131-138

Zambrano, L., Perrow, M. R., Macias-Garcia, C. and Aguirre-Hidalgo, V. (1999) Impact of introduced carp (Cyprinus carpio) in subtropical shallow pond in central Mexico. Journal of Aquatic Systems Stress Recovery 6: 281-288

Zampella, RA, Bunnell, JF, Laidig, KJ, Procopio, NA (2010) Aquatic degradation in shallow coastal plain lakes: Gradients or thresholds? Ecological Indicators 10: 303-310

Zhang, SY, Liu, AF, Ma, JM, Zhou, QH, Xu, D, Cheng, SP, Zhao, QA, Wu, ZB (2010) Changes in physicochemical and biological factors during regime shifts in a restoration demonstration of macrophytes in a small hypereutrophic Chinese lake. Ecological Engineering 36: 1611-1619

Zimmer, KD, Hanson, MA, Herwig, BR, Konsti, ML (2009) Thresholds and stability of alternative regimes in shallow Prairie-Parkland Lakes of Central North America. Ecosystems 12: 843-852 
Supplementary material S2. Number of shortlisted papers by continent and countries represented

\begin{tabular}{|l|c|l|}
\hline Continent & \# of papers & Countries represented \\
\hline Africa & 2 & South Africa \\
\hline Asia & 3 & China \\
\hline Europe & 10 & $\begin{array}{l}\text { Austria, Belgium, Finland, France, Hungary, Ireland, } \\
\text { Israel, Italy, Latvia, Lithuania, Netherlands, Norway, } \\
\text { Poland, Romania, Sweden, Switzerland, UK }\end{array}$ \\
\hline North America & 32 & Canada, Mexico, Panama, USA \\
\hline South America & 3 & Argentina, Brazil, Chile \\
\hline
\end{tabular}

Supplementary material S3. Number of shortlisted papers by climate zones and type of freshwater ecosystem (N.B. total is greater than 50 since several papers consider more than one ecosystem type)

\begin{tabular}{|l|c|c|c|c|}
\hline Climate zone & \multicolumn{4}{|c|}{ Ecosystem type } \\
\hline & $\begin{array}{c}\text { lakes and } \\
\text { ponds }\end{array}$ & $\begin{array}{c}\text { rivers \& } \\
\text { streams }\end{array}$ & $\begin{array}{c}\text { riparian / } \\
\text { floodplain }\end{array}$ & $\begin{array}{c}\text { other } \\
\text { wetlands* }\end{array}$ \\
\hline Arid \& semi-arid & 1 & 3 & 1 & \\
\hline Continental & 1 & 1 & & \\
\hline Sub-arctic & 3 & & & \\
\hline Subtropical & 7 & 1 & & 1 \\
\hline Temperate & 15 & 11 & 1 & 3 \\
\hline Tropical & 1 & 1 & & \\
\hline
\end{tabular}

* included intertidal wetlands, marshes and estuarine lagoons

Supplementary material S4. Number of shortlisted papers considering ecological responses of major freshwater taxa (N.B. total is greater than 50 since several papers consider more than one taxa)

\begin{tabular}{|l|c|}
\hline Taxa & \# of papers \\
\hline Amphibians & 2 \\
\hline Birds & 1 \\
\hline Fish & 9 \\
\hline Macroinvertebrates & 18 \\
\hline Macrophytes & 18 \\
\hline Phytoplankton & 15 \\
\hline Primary producers* & 8 \\
\hline Zooplankton & 5 \\
\hline
\end{tabular}

* typically Chl a 
Supplementary material S5. Number of shortlisted papers considering major types of pressures (N.B. total is greater than 50 since several papers consider more than one taxon)

\begin{tabular}{|l|c|}
\hline Taxa & \# of papers $^{-1}$ \\
\hline Anomalous weather $^{\mathrm{a}}$ & 4 \\
\hline Biodiversity change $^{\mathrm{b}}$ & 2 \\
\hline Climate change & 2 \\
\hline General anthropogenic pressure $^{\mathrm{a}}$ & 12 \\
\hline Hydrological change $^{\mathrm{a}}$ & 3 \\
\hline Land use change $^{\text {Physical habitat change }}{ }^{\mathrm{d}}$ & 5 \\
\hline Seasonal change $^{\text {Species introduction }}$ & 2 \\
\hline Urbanisation $^{\text {Water quality change }}$ & 7 \\
\hline None explicitly stated & 4 \\
\hline
\end{tabular}

a. hurricanes, storms etc.

b. general change in biological community structure, species loss, predator decline

c. including flow regime change, drought, water level fluctuations

d. including changes to sediment regime

Supplementary material S6. Period of ecological observation among shortlisted papers that were not space for time substitutions.

\begin{tabular}{|l|c|c|}
\hline Period of observation & $\begin{array}{c}\text { \# of non- } \\
\text { experimental } \\
\text { papers }\end{array}$ & $\begin{array}{c}\# \\
\text { experimental } \\
\text { papers }\end{array}$ \\
\hline Single survey & 2 & 2 \\
\hline$<=1$ year & 3 & 1 \\
\hline $1-5$ years & 2 & 3 \\
\hline $5-10$ years & 13 & 1 \\
\hline $10-20$ years & 6 & 1 \\
\hline$>20$ years & 7 & 0 \\
\hline
\end{tabular}

